\title{
Effect of Recurrent Impulse Load Actions on a Crane
}

The purpose of this numerical research is to study a derrick crane under repeated loads. The numerical analyses were carried out considering two different geometrical crane configurations, and two different rope lengths. After a preliminary analysis in order to evaluate both static and dynamic (modal) crane performance, many different analyses were carried out applying different load sequences. These actions were characterized by several impulse loads, which can be applied during the crane active use. Two parameters characterize the impulse load, i.e. the impulse duration and the delay between two successive actions. This load condition, which is not present in the crane design standards, was experimentally checked during the machine use in the marble quarry where it was installed. The results show that in specific crane configurations, characterized by the main arm position and the rope length and with a specific load sequences, both the vibration and the displacement magnitude increase in time, inducing high stress value in the crane components that can collapse the crane itself.

Keywords: dynamic load, impulse load, structural vibration, moving load, derrick crane.

\section{INTRODUCTION}

The main action that acts on the crane structure is due to the payload. In particular, in addition to the payload, it is very important to consider also the inertia action induced by moving the load that acts on the crane $[1,2,3]$, on the excavator [4], on the lifting equipment $[5,6]$ and on the trailers [7].

In general, these actions are evaluated by a specific coefficient that multiplies the nominal load value; through this simple procedure, it was estimated a load spectrum applied to the lifting machine [8].

The crane mechanical behaviour is completely different if we compare the actions induced by an earthquake or by the wind, with those induced by the moving load; in fact, the earthquake and wind actions are random and affect all crane parts $[9,10,11]$.

The application of a repeated load on the crane shows a completely different mechanical behaviour, especially for displacement intensity if compared to the load application and release, also sudden $[5,12,13]$.

The focus of this research regards the effect on the structure of the same crane reported in [12] subjected to a repeated impulse load.

A typical repeated actions appear when a jackhammer is applied to the excavator arm. In this case many repeated loads were applied to the machine structure itself [14]. This action type is frequent when it is necessary to position a component; in fact, in this case, in order to achieve a correct position many

Recevied: December 2019, Accepted: February 2020 Correspondence to: Prof. Dr Eng. Luigi Solazzi, University of Brescia, Department of Mechanical and Industrial Engineering, Brescia, Italy

E-mail: luigi.solazzi@unibs.it doi:10.5937/fme2002266S

(C) Faculty of Mechanical Engineering, Belgrade. All rights reserved impulse loads were applied by the operator.

For example, in construction engineering, to build a structure it is necessary to locate a component in a specific position; in this case, it is needful to apply many repeated actions for lifting and lowering the load. In this research many different impulse load sequences (impulse duration, delay between two successive impulses, impulse number, etc.) were numerical implemented to a derrick crane.

This crane was studied with two different geometrical configurations: the main arm in horizontal and in vertical position. In this numerical study, also the ropes were implemented because these components influence both the dynamic factor (due to the lifting operations) and the friction coefficient [15].

For each geometrical configuration two different rope lengths were assumed. The problem can be solved by analytical methods [16-17-18-19] however, the object of this research is very complex and the adoption of an analytical method could lead to excessive approximations.

The problem was solved by many numerical analyses, especially by finite element method technique.

As reported in the results section, this phenomenon is very important and dangerous; in fact, the displacement might increase and both the maximum stress value in the crane elements and the overturning moment increase.

In addition to these aspects, the repeated impulse load induces vibrations and fatigue phenomenon in the crane components [20,21,22].

For these aspects, the focus of this research is on studying the derrick crane subjected to a specific load condition, not included in the standard procedures for crane design, but the effects can be very dangerous for this type of lifting machines. 


\section{Crane description and FEM model}

The object of this research is a very large derrick crane. It consists of an arm with a length equal to $75 \mathrm{~m}$, a central tower with a height equal to $45 \mathrm{~m}$ and two struts whose length depends on the site where the crane was installed. In general, the strut angle of inclination is $45^{\circ}$ and so the length is approximately $60 \mathrm{~m}$.

All the structural elements are obtained by assembling elementary blocks made of a reticular structure. More details on a very similar crane are present in [12]. Figure 1 represents the crane object of this research.

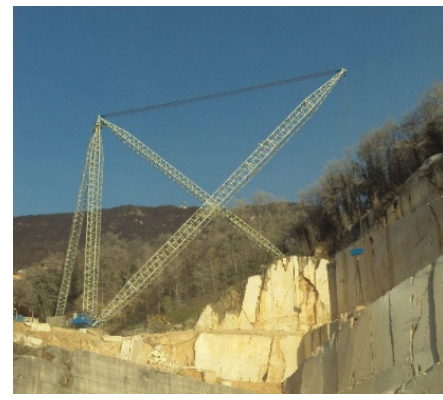

Figure 1 Derrick crane used in this research.

The geometrical configurations shown in this paper are two i.e. the crane with the arm angle equal to $85^{\circ}$ (vertical position) and with the arm angle equal to $5^{\circ}$ (horizontal position). In the first configuration the payload is equal to $60 \mathrm{t}$, while in the second configuration, this value is $30 \mathrm{t}$.

For each configuration two lengths of the load lifting ropes were considered, in particular a length equal to 0 $\mathrm{m}$, that represents the payload positioned at the arm end, and a length of the rope such as to be able to have the load at $-10 \mathrm{~m}$ from the support plane of the machine. For the $85^{\circ}$ configuration the rope length is equal to 90 $\mathrm{m}$ while for the other configuration this length is approximately $15 \mathrm{~m}$.

The rope to move both the arm and the payload is 6x36 Warrington-Seale with a diameter equal to $24 \mathrm{~mm}$. According to the equivalent number of rope sections, the equivalent stiffness was evaluated by (1):

$$
k_{i}=\frac{E \cdot A}{L_{i}}
$$

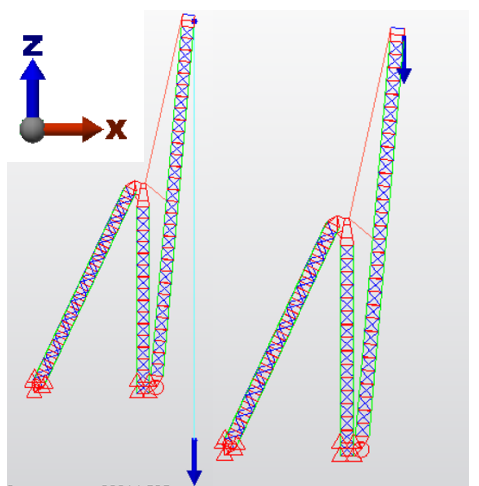

Figure 2. FEM model with arm position at $85^{\circ}$.

Once the rope stiffness value was determined in the finite element model (FEM), it was modelled with beam-spring type elements.
The FEM models (shown in figures 2 and 3), are made by means of quadratic formulation beam elements for a total of about 100,000 elements. The analyses were carried out with Autodesk Simulation ${ }^{\circledR}$ software.

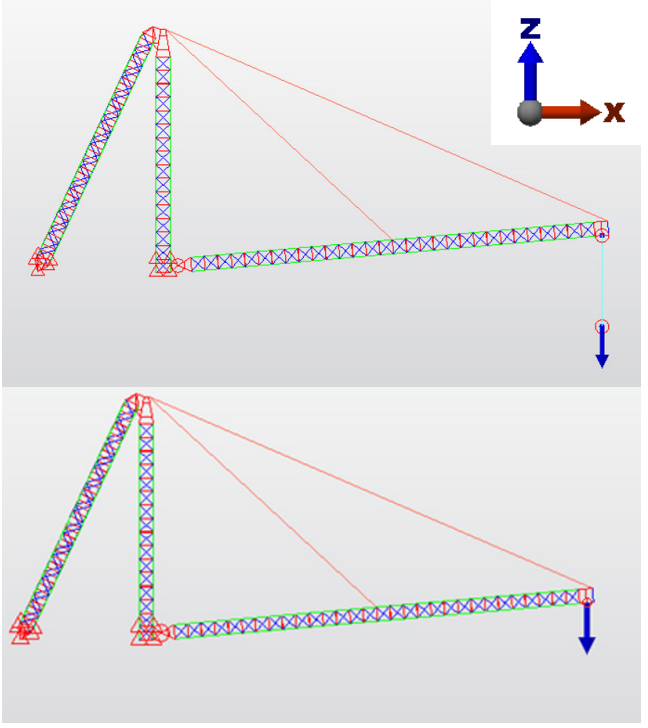

Figure 3. FEM model with arm positon at $5^{\circ}$.

\section{Static analyses results}

The load applied to the crane at $85^{\circ}$ geometrical configuration is $78 \mathrm{t}$. This value derives from the payload (equal to $60 \mathrm{t}$ ) to which must be added the weight of the accessories (ropes, hook, pulleys) equal to $5 \mathrm{t}$, all multiplied by a dynamic factor set to 1.2 . In the case of geometrical crane configuration at $5^{\circ}$ the load applied to the crane is equal to $42 \mathrm{t}$.

Figure 4 shows the crane displacement for the two geometrical configurations. The maximum displacement value for $5^{\circ}$ geometrical configuration it is $432.7 \mathrm{~mm}$ ( $19.1 \mathrm{~mm}$ in $\mathrm{x}$ direction and $-432.2 \mathrm{~mm}$ in $\mathrm{z}$ direction), while for $85^{\circ}$ geometrical configuration is equal to $318.9 \mathrm{~mm}(-60.1 \mathrm{~mm}$ in $\mathrm{z}$ direction and $313.4 \mathrm{~mm}$ in $\mathrm{y}$ direction).

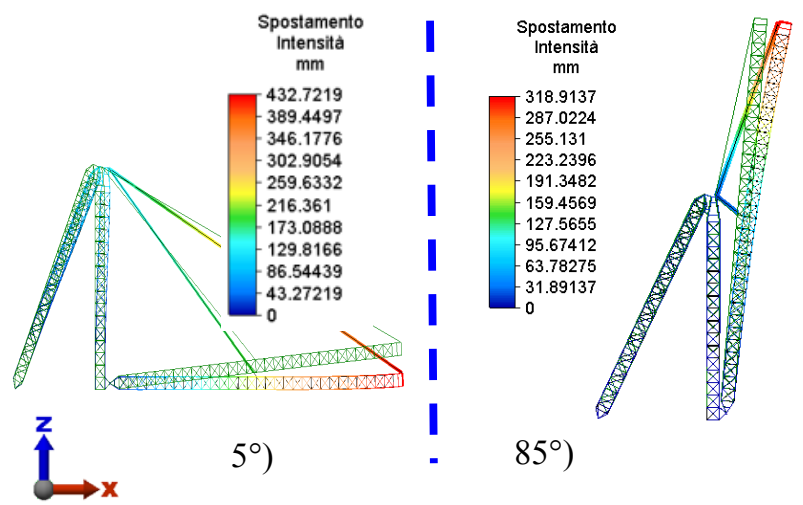

Figure 4. Crane displacement results for two geometrical configurations.

\section{Modal analyses results}

Figures 5, 6 and 7 show the structure displacement at the $85^{\circ}$ geometrical configuration. They refer to the first two vibration modes with the largest mass percentage in the three directions $(\mathrm{x}, \mathrm{y}$ and $\mathrm{z})$. Table 1 
shows the values for the $85^{\circ}$ configuration while Table 2 reports the values for the $5^{\circ}$ configuration. For both configurations the sum of the participating mass involved in the vibration modes considering the first 60 natural frequencies is greater than $85 \%$ of total mass.

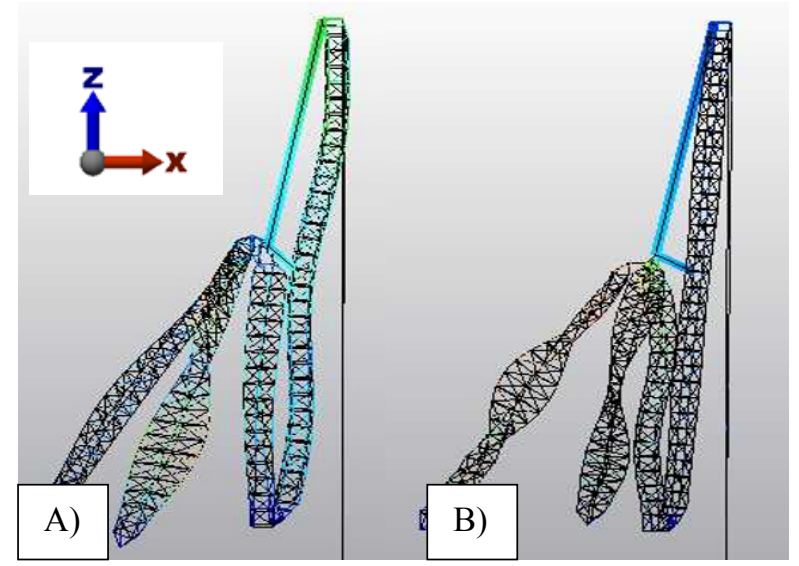

Figure 5 FEM model deformation in z direction: A) $11.96 \mathrm{~Hz}$; B) $22.47 \mathrm{~Hz}$.

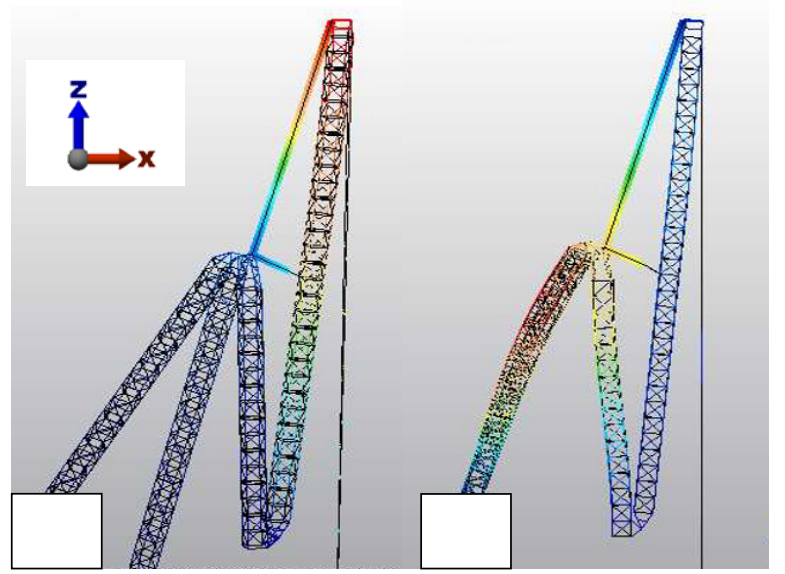

Figure 6 FEM model deformation in $\mathrm{x}$ direction: A) $0.816 \mathrm{~Hz}$; B) $2.81 \mathrm{~Hz}$.

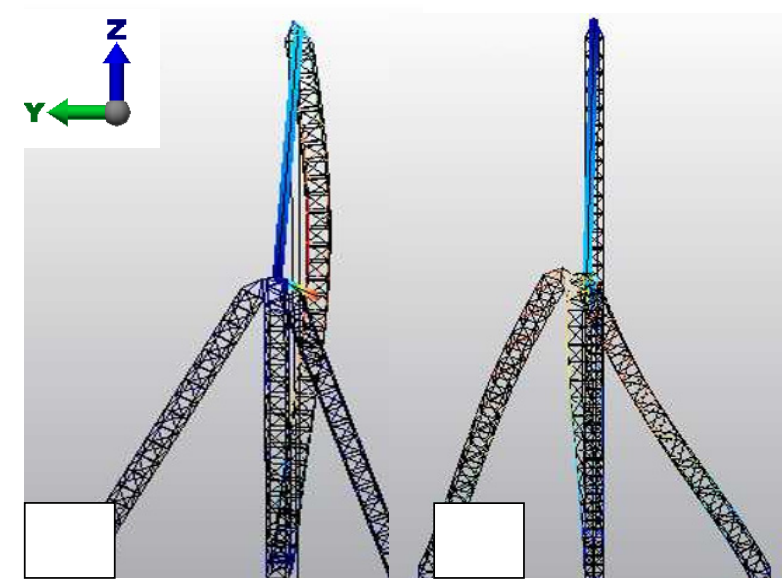

Figure 7 FEM model deformation in y direction: A) $1.619 \mathrm{~Hz}$; B) $2.730 \mathrm{~Hz}$.

From the values of the natural frequencies reported in tables 1 and 2, it emerges that the structure presents distinct vibration modes in the three directions. From the comparison of the natural frequency values with and without a rope for payload moving, it emerges that, in general, the rope induces further vibration modes. These natural frequencies are associated with a low mass rate because the weight of the rope constitutes a small percentage of the total weight crane.

Table 1. Natural frequencies and mass rate at $85^{\circ}$ geometrical configuration.

\begin{tabular}{|c|c|c|c|c|}
\hline Mode & $\begin{array}{c}\text { Freq. } \\
{[\mathrm{Hz}]}\end{array}$ & $\begin{array}{c}\mathrm{X}_{-} \text {Mass } \\
{[\%]}\end{array}$ & $\begin{array}{c}\mathrm{Y}_{-} \text {Mass } \\
{[\%]}\end{array}$ & $\begin{array}{c}Z_{-}[\%] \\
{[\%]}\end{array}$ \\
\hline 2 & 0.816 & 34.31 & 0.00 & 0.05 \\
\hline 3 & 1.619 & 0.00 & 25.61 & 0.02 \\
\hline 6 & 2.730 & 1.14 & 32.08 & 0.18 \\
\hline 7 & 2.811 & 35.88 & 0.72 & 2.52 \\
\hline 32 & 10.257 & 0.04 & 0.00 & 11.96 \\
\hline 53 & 17.760 & 2.49 & 0.01 & 22.47 \\
\hline
\end{tabular}

Table 2. Natural frequencies and mass rate at $5^{\circ}$ geometrical configuration.

\begin{tabular}{|c|c|c|c|c|}
\hline Mode & $\begin{array}{c}\text { Freq. } \\
{[\mathrm{Hz}]}\end{array}$ & $\begin{array}{c}\mathrm{X}_{-} \text {Mass } \\
{[\%]}\end{array}$ & $\begin{array}{c}\mathrm{Y}_{-} \text {Mass } \\
{[\%]}\end{array}$ & $\begin{array}{c}Z_{-} \text {Mass } \\
{[\%]}\end{array}$ \\
\hline 2 & 1.094 & 3.00 & 0.00 & 34.90 \\
\hline 3 & 1.669 & 0.00 & 25.91 & 0.00 \\
\hline 5 & 2.732 & 0.01 & 33.06 & 0.02 \\
\hline 8 & 3.481 & 22.14 & 2.68 & 0.14 \\
\hline 32 & 10.820 & 21.52 & 0.01 & 0.05 \\
\hline 47 & 17.435 & 2.72 & 0.02 & 28.25 \\
\hline
\end{tabular}

\section{Definition of laod conditions and numerical analysis procedure}

In the event that a component needs to be moved to a specific position, it often happens that the operator repeatedly executes the commands in order to reach the desired position. This load condition is not present in the crane design standards and its definition is quite approximate as a consequence of the fact that it depends both on the operator assigned to the machine, on the lifting device and on the load to be handled.

Through a series of experimental tests, it was noted that the time of the operator's action is very short and that the pause between one command and the next is variable.

These observations were conducted both in the marble quarry where the derrick crane is present, and in a mechanical firm where similar operations were checked for positioning a steel block on a work centre by means of an overhead crane.

For this reason, it was decided to study this effect with a load sequence composed by three load impulse whose duration is the same for all, i.e. $\mathrm{A}=0.1 \mathrm{~s}$ while the delay between two repeated operations is variable and in particular $\mathrm{B}=0.3,0.5$ and $0.8 \mathrm{~s}$ (figure 8).

All numerical analyses were conducted in the linear elastic range using Autodesk Simulation ${ }^{\circledR}$ software. The procedure adopted to resolve the dynamics equations is direct integration method; what is fundamental for this technique is the integration step parameter which was assumed after a series of analyses performed, in order to achieve the convergence of the numerical solution obtained. This value was assumed equal to $0.0005 \mathrm{~s}$.

Another fundamental parameter is the damping value which was assumed equal to $5 \%$ of the critical 
damping (plausible value for these types of structures). The damping value (2) in the matrix [C] depends on the parameters $\alpha$ and $\beta$ which multiply both the mass matrix $[\mathrm{M}]$ and the stiffness matrix [K]. These parameters $\alpha$ and $\beta$ are the Rayleigh coefficients whose values vary, depending on the geometric configuration of the crane and the presence or absence of the rope. In particular, the $\alpha$ value changes in the range $0.06-1.6$ while the $\beta$ value varies in the range $0.0006-0.0008$.

$$
[C]=\alpha[M]+\beta[K]
$$

The load applied to the crane is equal to the $25 \%$ of the working load limit for each specific configuration; in particular, for first geometrical configuration $\left(85^{\circ}\right)$, the load is equal to $15 \mathrm{t}$, while the value is equal to $7.5 \mathrm{t}$ for the second configuration $\left(5^{\circ}\right)$.

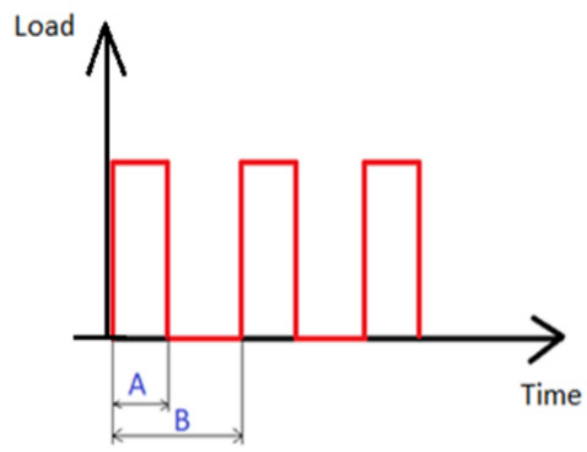

Figura 8 Schematization of the repeated impulse load applied to the crane.

\section{Results at $85^{\circ}$ geometrical configuration}

The next paragraphs report the main numerical results acquired by FEM analyses.

\section{$6.185^{\circ}$ Geometrical configuration}

Figures 9, 10 and 11 report the displacement in $\mathrm{x}$ direction acquired at the arm end for three different load sequences. The results concerning the configuration without the rope for fixing the payload.

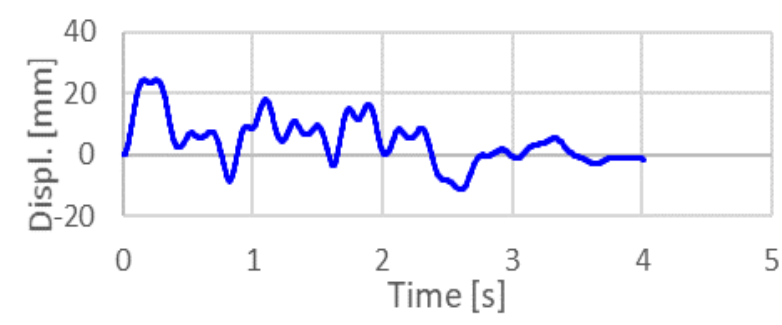

Figure 9. End arm x-displacement: $A=0.1 \mathrm{~s}$ and $B=0.8 \mathrm{~s}$.

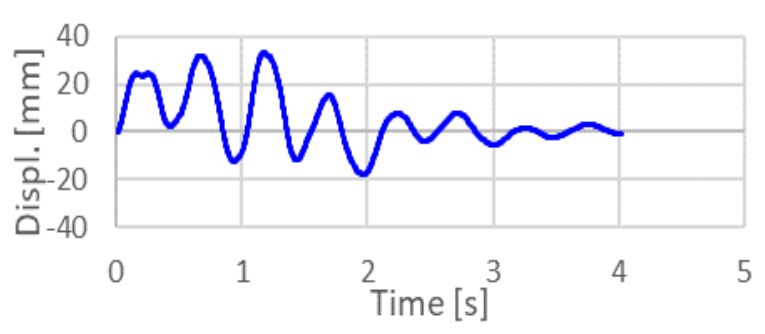

Figure 10. End arm $x$-displacement: $A=0.1 \mathrm{~s}$ and $B=0.5 \mathrm{~s}$.

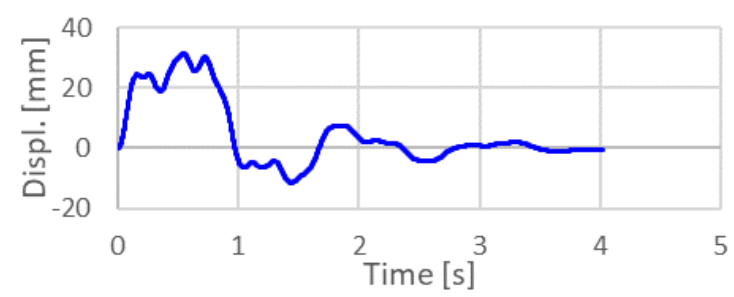

Figure 11. End arm $x$-displacement: $A=0.1 \mathrm{~s}$ and $B=0.3 \mathrm{~s}$.

\section{$6.25^{\circ}$ Geometrical configuration}

Figure 12, 13 and 14 report the displacement in $\mathrm{z}$ direction acquired at the arm end for three different load sequences. The results concerning the configuration without the rope for fixing the payload.

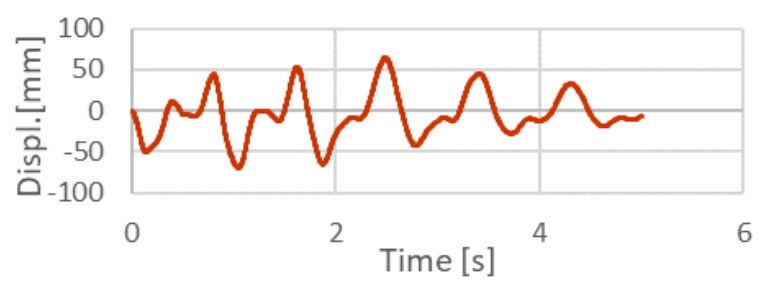

Figure 12. End arm z-displacement: $A=0.1 \mathrm{~s}$ and $B=0.8 \mathrm{~s}$.

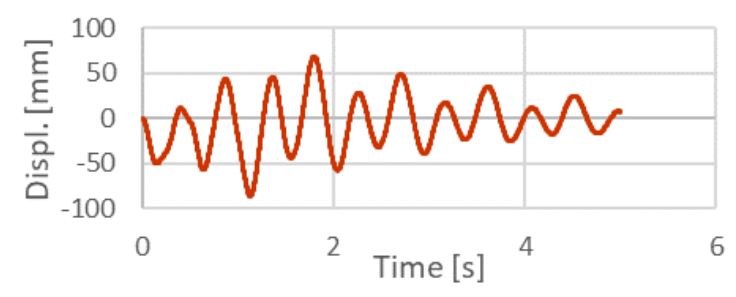

Figure 13. End arm z-displacement: $A=0.1 \mathrm{~s}$ and $B=0.5 \mathrm{~s}$.

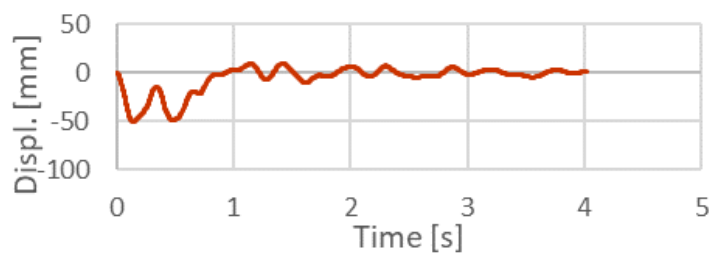

Figure 14. End arm z-displacement: $A=0.1 \mathrm{~s}$ and $B=0.3 \mathrm{~s}$.

\subsection{Remarks}

The results for the two geometrical configurations show a progressive increase of displacement especially for $\mathrm{A}=0.1 \mathrm{~s}$ and $\mathrm{B}=0.5 \mathrm{~s}$ parameters for $85^{\circ}$ configuration and for $\mathrm{A}=0.1 \mathrm{~s}$ and $\mathrm{B}=0.8 \mathrm{~s}$ and $0.5 \mathrm{~s}$ for $5^{\circ}$ configuration. It is possible also to observe that the displacement value, in some load conditions, changes in sign.

\section{Rope length effect}

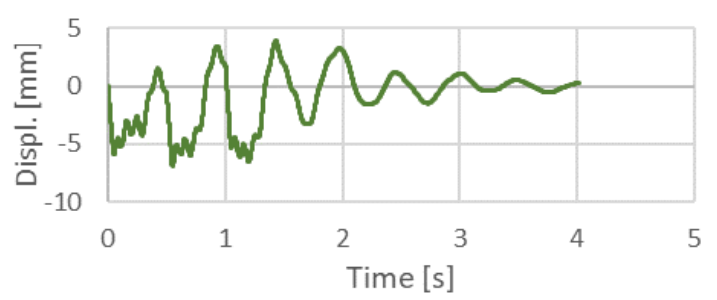

Figure 15. End arm $z$ displacement: $A=0.1 \mathrm{~s}$ and $B=0.5 \mathrm{~s}$, without rope. 


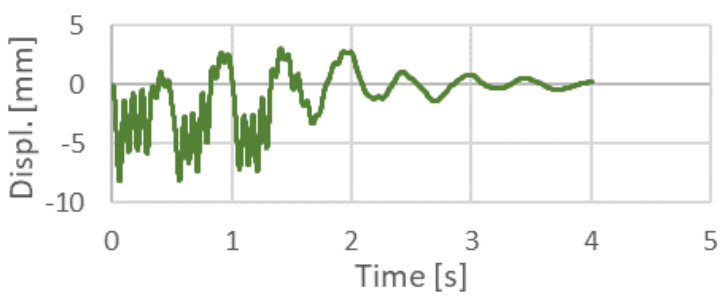

Figure 16. End arm $z$ displacement: $A=0.1 \mathrm{~s}$ and $B=0.5 \mathrm{~s}$, with rope.

Figures 15 and 16 show the displacement in $\mathrm{z}$ direction for the $85^{\circ}$ geometrical configuration with $A=0.1 \mathrm{~s}$ and $\mathrm{B}=0.5 \mathrm{~s}$ parameters with and without the rope for fixing the payload. By comparing of these figures, it is evident that the rope presence induces more vibrations in the crane structure (in this case the rope length is equal to $90 \mathrm{~m})$ respect to the situation without the rope.

\section{Relation beetween Impulse load actions and crane naural frequncies}

Table 3 shows the correlation between the parameters A and $B$ which define the load sequences with the first crane natural frequency for both $85^{\circ}$ and $5^{\circ}$ geometrical configurations without the rope.

Table 3. Natural frequencies and A e B parameters.

\begin{tabular}{|c|c|c|}
\cline { 2 - 3 } \multicolumn{1}{c|}{} & $\begin{array}{c}85^{\circ} \text { Geometrical } \\
\text { configuration }\end{array}$ & $\begin{array}{c}5^{\circ} \text { Geometrical } \\
\text { configuration }\end{array}$ \\
\hline Freq. [Hz] & 1.346 & 0.719 \\
\hline $\mathrm{A}[\mathrm{s}]$ & 0.1857 & 0.3479 \\
\hline $\mathrm{B}[\mathrm{s}]$ & 0.7430 & 1.3916 \\
\hline
\end{tabular}

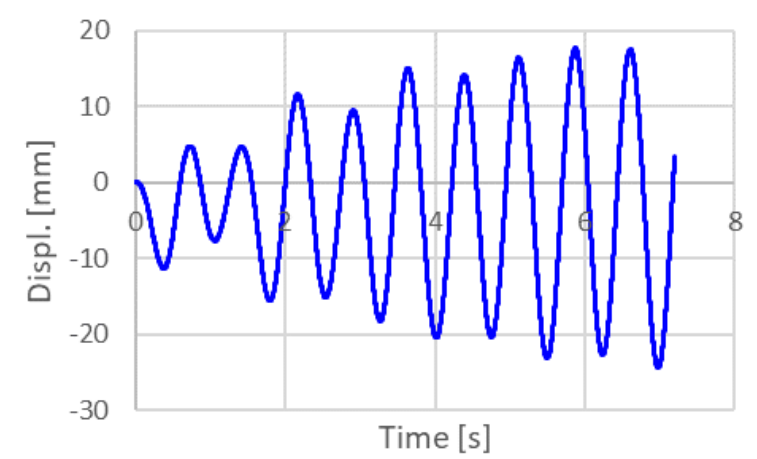

Figure 17. End arm z displacement, $85^{\circ}$ configuration.

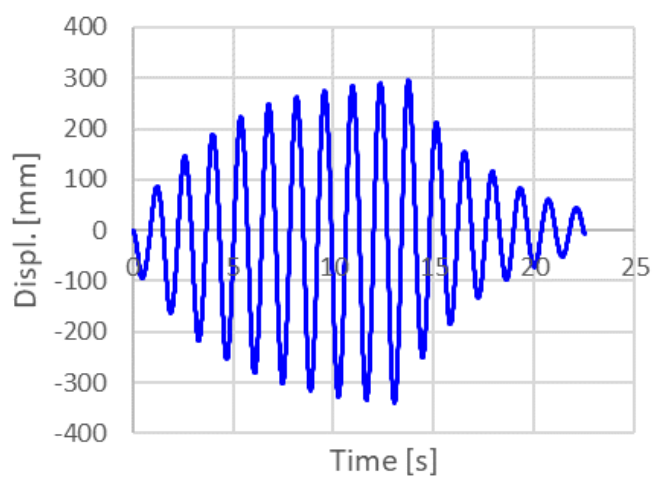

Figure 18. End arm z displacement, $5^{\circ}$ configuration.

Figure 17 and 18 show the displacement at the end arm of this derrick crane for these specific load conditions which depend on the $\mathrm{A}$ and $\mathrm{B}$ parameters. The results concern a sequence composed by ten impulse load. It is important to highlight that this load condition can be really applied in the normal operation while using a crane. From the graphs it is possible to underline that the displacement continuously increases in time.

\section{CONCLUSIONS}

The present work reports the results of numerical analyses carried out using the finite element technique on a particular high performance derrick crane. The purpose of this research was to evaluate the dynamic behaviour of the crane which was subjected to a series of impulse load. This load condition is not present in the crane design standards but may occur operationally during its use. To respond to the research purpose, 4 different crane configurations were studied, that is, with a $85^{\circ}$ and a $5^{\circ}$ arm position and with or without a load moving rope.

The crane was characterized both statically and dynamically (by modal analysis) also evaluating the influence of the presence or not of lifting rope. The load handling operations through impulsive action, defined by the impulse duration and by the temporal delay between two consecutive pulses, generates a series of vibrations whose magnitude is dependent on the crane configuration and the sequence of impulse load. In the configuration in which the load sequences parameters bring the external action with the frequency near to the crane ones (absolutely plausible in-service load condition), it is possible to observe a progressive increase in displacements and their divergence over time. This aspect induces obviously an increase in the stresses values, on all the machine components (structure, ropes, winches, motors and gearbox) which can also lead to the collapse of the machine itself. Based on these results, it emerges that the load condition given by a series of impulse load must be further investigated also on other lifting devices. The objectives of future research are two: the first is to make experimental tests in order to confirm the load conditions and the crane mechanical behaviour and the second to correlate the lifting equipment natural frequencies with the parameters that characterize the load sequences, in order to avoid these load conditions (for example through by a specific electronic control unit) that are very dangerous for the crane.

\section{REFERENCES}

[1] Yildirim, Ş., Esim, E.: A new approach for dynamic analysis of overhead crane systems under moving loads, Lectures Notes in Electrical Engineering, Vol. 402, 471-481, 2017.

[2] Rupar, D., Hladnik, J., Jerman, B.: Loader crane inertial forces, FME Transections, Vol. 44 (3) 291$297,2016$.

[3] Solazzi, L., Incerti, G., Petrogalli, C.: Estimation of the dynamic effect in the lifting operations of a boom crane. Proceeding of the 28 European Conference on Modelling and Simulation, Brescia, Italy, 309-315, 27-30 May 2014.

[4] Solazzi, L., Assi, A., Ceresoli, F.: Excavator arms: numerical, experimental and new concept design, Composite Structures, Vol. 217, 60-74, 2019. 
[5] Solazzi, L.: Experimental and analytical study on elevating working platform. Procedia Engineering, Vol. 199, 2597-2602, 2017.

[6] Solazzi, L.: New design concept for lifting platform made of composite material. Applied composite materials, Vol. 20 (4), 615-626, 2013.

[7] Solazzi, L.: Applied research for Weight Reduction of an industrial Trailer, FME Transactions, Vol. 40, 57-62, 2012.

[8] Rahbar-Ranji, A.: Dynamic magnification factor in a box shape steel girder, Journal of the Institution on Engineers (India): Series C, Vol. 95 (1), 11-18, 2014.

[9] Solazzi, L.: Ship to shore crane subject to earthquake. Procedia Engineering, Vol. 10, 26902695, 2011.

[10] Wang, D., Wang, G., Xiong, Y., Hu, J.: Analysis of nonlinear dynamic second order effect of a large scale container crane under seismic excitations, Mechanisms and Machine Science, Vol. 23, 889899, 2015.

[11] Solazzi, L., Zrnić, N.: Numerical study of wind actions applied to a low profile container crane. FME Transactions, Vol. 44, 29-35, 2016.

[12] Solazzi, L., Zrnić, N.: Design of a high capacity derrick crane considering the effects induced by load application and release. Journal of Applied Engineering Science, Vol. 15 (1), 15-24, 2017.

[13] Haniszewski, T.: Preliminary modelling studies of sudden release of a part of the hoist load with using experimental miniature test crane, Vibroengineering Procedia, Vol. 13,193-198, 2017.

[14] Jiong, L., Yu, W., Kai, Z., Zhiqiao, W., Jixiang, L.: Design analysis of demolition robot arm based on finite element method. Advance in Mechanical Engineering, Vol. 11 (6), 1-9, 2019.

[15] Yang, S., Fang, X., Zhang, J., Wand, D.: Dynamic behaviour of bridge erecting machine subjected to moving mass suspended by wire ropes. Applied Mathematics and Mechanics, Vol. 37 (1) 741-748, 2016.

[16] Lin, G.Y., Li, Z. Y., Wang, Z. G., Li, K. X.: A calculation of the crawler crane boom system's dynamic load in the lifting process. Dongbei Daxue Xuebao Journal of Northeaster University, Vol. 36 (5) 699-703, 2015.

[17] Lin, G. Y., Cao, S. Q., Guo, C. J.: Analysis and control the influence factors on the dynamic load coefficient of the crawler crane working mechanism. Advanced materials research, Vol. 945, 626-632, 2014.

[18] Posiadala, B., Warys, P., Cekus, D., Tomala, M.: The dynamics of the forest crane during the load carrying. International journal of structural stability and dynamics, Vol. 13 (7), 2013.

[19] Liu, J., Zhou, G., Han, G. Simulation model for in service rig derrick based on finite dynamic model. Shiyou Xuabao, Acta Petrolei Sinca, Vol. 30 (5), 788-792, 2009.

[20] Zaretsky, A.A., Shapiro, H.I.: Overturning stability of a free standing crane under dynamic loading. SAE Technical Papers, International Off Highway and Powerplant Congress and Exposition, Milwaukee, WI, 8-10 September 1997.

[21] Ogrinec, P., Slavič, J., Cesnik, M., Boltežar, M.: Vibration fatigue at half sine impulse excitation in the time and frequencies domains. International Journal of Fatigue, Vol. 123, 308-317, 2019.

[22] Li, X.,Yan, X., Shuai, F., Shen, Y.: Study on estimation fatigue life of main girder of portal crane. Proceedings of 2018 Prognostics and system health management conference PHM, Chongqing, China, 1132-1237, 4 January 2019

\section{УТИЦАЈ ПОНАВЉАНОГ ИМПУЛСНОГ ОПТЕРЕЋЕЊА НА ДИЗАЛИЦУ}

\section{Л. Солаци}

Рад се бави нумеричким истраживањем утицаја понављаног оптерећења на дерик дизалицу. Истраживањем су обухваћене две различите геометријске конфигурације дизалице и две различите дужине ужета. После прелиминарне евалуације статичких и динамичких перформанси дизалице извршене су анализе применом различитих циклуса оптерећења. Примењено је више импулсних оптерећења током активног коришћења дизалице. Импулсно оптерећење одликују два параметра: трајање оптерећења и кашњење између његова два узастопна деловања. Стање оптерећења, које не постоји у стандардима за пројектовање дизалице, експериментално је проверено инсталирањем дизализе за рад у каменолому. Резултати показују да се код специфичне конфигурације дизалице, коју одликује положај главне стреле, дужина ужета и циклуси оптерећења, вибрације и магнитуда помераја повећавају у времену, што изазива пораст вредности напона код компонената дизалице, а што би могло да доведе до њеног рушења. 